J. Clin. Chem. Clin. Biochem.

Vol. 24, 1986, pp. $437-440$

(C) 1986 Walter de Gruyter \& Co. Berlin - New York

\title{
Glandular Kallikrein, Renin and Tonin in Tissues of Diabetic and Hypertensive Rats
}

\author{
By Wataru Sakamoto, Katsumi Yoshikawa, Atsuro Yokoyama, Masaki Kohri \\ Department of Biochemistry, School of Dentistry, Hokkaido University, Sapporo, Japan
}

Hiroshi Handa, Soichiro Uehara, Akio Hirayama

Tonan Hospital, Sapporo, Japan and

Hiroshi Izumi

Department of Physiology, School of Dentistry, Tohoku University, Sendai, Japan

(Received September 25/December 20, 1985)

Summary: The submaxillary gland and kidney of diabetic and hypertensive rats were compared for their content of glandular kallikrein and the activities of tonin and renin. The submaxillary glands and the kidneys of both diabetic Wistar strain and hypertensive rats contained significantly less glandular kallikrein than non-diabetic Wistar strain and hypertensive rats (reduction from 40 to $76 \%$ ). The renin activity of the kidney showed only a slight change in spite of diabetes, whereas the activity of the submaxillary gland decreased in parallel with the reduction of the kallikrein content when diabetes was induced. On the other hand, the tonin of the submaxillary gland, which has a potent hypertensive activity like renin, was not affected by induction of diabetes. However, the tonin activity in hypertensive rats was significantly higher $(p<0.001)$ than that in the normotensive rats (His-Leu, $168.7 \pm 10.1$ vs. $131.5 \pm 17.3 \mathrm{nmol} / \mathrm{min} \cdot \mathrm{mg}$ protein).

\section{Drüsen-Kallikrein, Renin und Tonin in Geweben diabetischer und hypertensiver Ratten}

Zusammenfassung: Die Gl. submaxillaris und die Niere diabetischer und hypertensiver Ratten werden hinsichtlich ihres Gehalts an Drüsen-Kallikrein sowie ihrer Aktivitäten an Tonin und Renin verglichen. Die Gl. submaxillaris und die Nieren der diabetischen Wistar-Ratten und der zugleich hypertensiven Ratten enthielten signifikant weniger Drüsen-Kallikrein als die nicht-diabetischer Wistar-Ratten und hypertensiver Ratten (Verminderung zwischen 40 und 76\%). Die Renin-Aktivität der Nieren zeigte nur geringe Änderungen durch den Diabetes, während die der Gl. submaxillaris parallel zur Verminderung des Kallikreingehalts verlief, wenn Diabetes ausgelöst wurde. Andererseits war Tonin, das Renin-ähnlich wirkt, in der Gl. submaxillaris durch den Diabetes nicht beeinflußt, jedoch bei hypertensiven Ratten signifikant höher $(p<0,001)$ als bei normotensiven Ratten (Hiṣ-Leu, 168,7 \pm 10,1 gegenüber 131,5 $\pm 17,3 \mathrm{nmol} / \mathrm{min} \cdot \mathrm{mg}$ Protein).

\section{Introduction}

Glandular kallikrein, an enzyme of the serine proteinase family, is known to act on a natural substrate of plasma, kininogen, to release a vasodilator peptide, kinin (1). On the other hand, renin in salivary gland and kidney is known to act on a natural substrate of plasma, angiotensinogen, to release angiotensin I. The latter is converted to angiotensin II, vasopressor peptide, by angiotensin converting enzyme $(2,3)$. Tonin, another enzyme of the serine protease family, 
is present in salivary gland and has been known not only to convert angiotensin I to angiotensin II, but also to generate angiotensin II from a natural substrate of renin, the angiotensinogen (4).

In our previous papers, we have reported that the kallikrein levels in the submaxillary gland and pancreas of diabetic rats were significantly lower than those of normal rats, and that the submaxillary gland and pancreatic levels in hypertensive rats tended to be higher than in normal rats (5). Suzuki et al. have reported that there are close interactions between the kallikrein-kinin system and renin-angiotensin system (6).

The purpose of this present study was to clarify the relationship between the contents of kallikrein, renin and tonin in the submaxillary gland and kidney of diabetic and hypertensive rats.

\section{Materials and Methods}

Male Wistar strain rats, spontaneously hypertensive rat strain and Wistar-kyoto strain (weighing $150-200 \mathrm{~g}$ and $7-8$ weeks old) were purchased from the Institute for animal experiment, School of Medicine, Hokkaido University.

Streptozotocin-diabetic rats were induced by a single intravenous injection of streptozotocin $(70 \mathrm{mg} / \mathrm{kg})$.

Twenty eight days after injection of streptozotocin, the blood of treated and control rats were obtained by cardiac puncture with $1 / 10$ volumes of $38 \mathrm{~g} / \mathrm{l}$ trisodium citrate, under light ethylether anaesthesia.

After blood collection, the kidney and the submaxillary gland were carefully removed from each animal, washed in saline to remove any traces of blood, and immediately frozen at $-30^{\circ} \mathrm{C}$ to be stored until use.

The levels of blood glucose and systolic pressure of rats were measured by glucose oxidase method (7) and tail cuff sphygmography.

Protein was determined by the method of Lowry et al. (8), using bovine serum albumin as the standard.

The homogenates of the submaxillary gland and the kidney were prepared in $10 \mathrm{mmol} / \mathrm{l}$ sodium phosphate buffer ( $\mathrm{pH} 6.0$ ), containing $100 \mathrm{mmol} / \mathrm{l} \mathrm{NaCl}(1 \mathrm{~g}$ of tissue per $9 \mathrm{ml}$ of buffer), using a Polytron homogenizer. Homogenates were centrifuged for $20 \mathrm{~min}$ at $10000 \mathrm{~min}^{-1}$. The supernatant was used for the measurement of kallikrein, tonin, and renin.

The contents of glandular kallikrein in the submaxillary gland and kidney was measured by specific enzyme immunoassay as described previously (5).

Renin activity was measured by the rate of generation of angiotensin I in nephrectomized rat plasma (substrate) as follows: after incubation with substrate $(25 \mu \mathrm{l})$ at $37^{\circ} \mathrm{C}$ for $1 \mathrm{~h}$ in 100 $\mathrm{mmol} / 1$ maleate buffer ( $\mathrm{pH} 6.5$ ) containing $6.0 \mathrm{mmol} / 1$ EDTA and $2.0 \mathrm{mmol} / 1$ phenylmethanesulphonyl fluoride.

Angiotensin I was determined by the radioimmunoassay methods of Inagami \& Murakami (9), and Haber et al. (10).

Tonin activity was measured in a $3.0 \mathrm{ml}$ incubation mixture containing $50 \mathrm{mmol} / \mathrm{l}$ boraxphosphate buffer (pH 7.0) as described previously (11). EDTA $(4.3 \mathrm{mmol} / \mathrm{l})$, phenylmethanesul- phonyl fluoride $(1.43 \mathrm{mmol} / \mathrm{l})$ and dipyridyl $(0.141 \mathrm{mmol} / \mathrm{l})$ were added to the buffer solution to inhibit the angiotensin Iconverting enzyme activity. The reaction was initiated by the addition of the substrate (angiotensin I, $100 \mu \mathrm{g}$ per tube) and the reaction mixture was incubated at $37^{\circ} \mathrm{C}$ for $30 \mathrm{~min}$. Reactions were terminated by the addition of $0.4 \mathrm{ml}$ of $2 \mathrm{~mol} / 1$ $\mathrm{NaOH}$. To this reaction mixture, ; 9 -phthalaldehyde reagent $(1 \mathrm{~g} / 1$ methanol, prepared freshly daily) $(0.1 \mathrm{ml})$ was added, then mixed with shaking. Four minutes later at room temperature, $3.5 \mathrm{~mol} / 1$ orthophosphoric acid $(0.4 \mathrm{ml})$ was added to the mixture. The fluorescence was measured at $440 \mathrm{~nm}$ with excitation at $360 \mathrm{~nm}$. The concentration of His-Leu released was calculated by a comparison of the fluorescence produced with standard solutions.

\section{Results}

Kallikrein content and renin and tonin activities in the submaxillary gland homogenates of normal, diabetic and hypertensive rats

As shown in table 1, the content of kallikrein in the submaxillary gland homogenates was $73.5 \pm 27.2$ and $66.3 \pm 7.0 \mu \mathrm{g} / \mathrm{mg}$ protein in normal rats (Wistar and Wistar-kyoto strains), $17.4 \pm 9.9$ in diabetic Wistar strain rats, $78.4 \pm 8.0$ in hypertensive rats, and $20.4 \pm 6.4$ in diabetic hypertensive rats. On the other hand, the specific activity of renin in hypertensive rats was $152.7 \pm 14.55 \mathrm{ng}$ angiotensin I per $\mathrm{h} \cdot \mathrm{mg}$ protein, with a significant difference $(p<0.001)$ from that in normotensive rats $(89.7 \pm$ 13.30). However, the activity was reduced in both diabetic Wistar strain and hypertensive rats, namely to $20.9 \pm 6.58$ and $33.0 \pm 9.66$, respectively. On the other hand, the tonin activity of the submaxillary gland was not reduced even though diabetes was induced by streptozotocin injection; the tonin activities of the diabetic Wistar and hypertensive rats were $86.4 \pm 6.82$ and $170.2 \pm 5.97$ nmol His-Leu per min $\cdot \mathrm{mg}$ protein, respectively. In contrast to diabetes, the control value in the Wistar rats was $98.1 \pm 4.21$ nmol His-Leu per min $\cdot \mathrm{mg}$ protein, and 131.5 17.3 in Wistar-kyoto strain rats. The activity of the hypertensive rats was $168.7 \pm 10.10$ nmol His-Leu per min $\cdot \mathrm{mg}$ protein, with a significant difference $(p<0.001)$ from that in normotensive rats.

\section{Kallikrein content and renin activity in the kidney homogenates of normal, diabetic and hypertensive rats}

The content of kallikrein in the kidney homogenates was very small in comparison with the submaxillary gland, as shown in table 2. As in the submaxillary gland, the kallikrein content of kidney homogenate decreased in the pathogenesis of experimental diabetes. The values were $8.1 \pm 1.09 \mathrm{ng} / \mathrm{mg}$ protein in normal rats (Wiatar), $4.6 \pm 1: 98$ in Wistar diabetic rats, and $3.7 \pm 2.26$ in diabetic hypertensive rats. 
Tab. 1. Kallikrein content, renin and tonin activities in the submaxillary gland of control, streptozotocin-diabetic, and spontaneously hypertensive rats.

\begin{tabular}{|c|c|c|c|c|c|}
\hline & $\begin{array}{l}\text { Kallikrein } \\
\text { content } \\
(\mu \mathrm{g} / \mathrm{mg} \\
\text { protein) }\end{array}$ & $\begin{array}{l}\text { Renin activity } \\
\text { (angiotensin I, } \\
\mathrm{ng} / \mathrm{h} \cdot \mathrm{mg} \\
\text { protein) }\end{array}$ & $\begin{array}{l}\text { Tonin activity } \\
\text { (His-Leu, } \\
\text { nmol/min } \cdot \mathrm{mg} \\
\text { protein) }\end{array}$ & $\begin{array}{l}\text { Blood } \\
\text { pressure } \\
(\mathrm{mm} \mathrm{Hg})\end{array}$ & $\begin{array}{l}\text { Blood } \\
\text { glucose } \\
(\mathrm{mmol} / \mathrm{l})\end{array}$ \\
\hline \multicolumn{6}{|l|}{ Wistar strain } \\
\hline $\begin{array}{ll}\text { Control } & (\mathrm{n}=11) \\
\text { Diabetic } & (\mathrm{n}=10)\end{array}$ & $\begin{array}{l}73.5 \pm 27.2^{*} \\
17.4 \pm 9.9\end{array}$ & $\begin{array}{c}108.4 \pm 22.18^{*} \\
20.9 \pm 6.58\end{array}$ & $\begin{array}{l}98.1 \pm 4.21^{*} \\
86.4 \pm 6.82\end{array}$ & $\begin{array}{l}\text { N.D. } \\
\text { N.D. }\end{array}$ & $\begin{aligned} 7.7 & \pm 1.16^{*} \\
21.7 & \pm 2.44\end{aligned}$ \\
\hline \multicolumn{6}{|l|}{ Wistar-kyoto strain } \\
\hline $\begin{array}{ll}\text { Normotensive } & (n=10) \\
\text { Hypertensive } & (n=10) \\
\text { Hypertensive + Diabetic } & (n=6)\end{array}$ & $\begin{array}{l}66.3 \pm 7.0 \\
78.4 \pm 8.0 \\
20.4 \pm 6.4\end{array}$ & $\begin{array}{r}89.7 \pm 13.30 \\
152.7 \pm 14.55 \\
33.0 \pm 9.66\end{array}$ & $\begin{array}{l}131.5 \pm 17.3 \\
168.7 \pm 10.10 \\
170.2 \pm 5.97\end{array}$ & $\begin{array}{l}99.1 \pm 8.5^{*} \\
185.0 \pm 12.3 \\
192.0 \pm 14.8\end{array}$ & $\begin{array}{r}7.5 \pm 0.64 \\
6.4 \pm 0.88 \\
22.0 \pm 2.16\end{array}$ \\
\hline
\end{tabular}

* Standard deviation; N.D., not determined.

Tab. 2. Kallikrein content and renin activity in the kidney of control, streptozotocin-diabetic, and spontaneously hypertensive rats.

\begin{tabular}{|c|c|c|}
\hline & $\begin{array}{l}\text { Kallikrein content } \\
\text { (ng/mg protein) }\end{array}$ & $\begin{array}{l}\text { Renin activity } \\
\text { (angiotensin } \mathrm{I}, \mathrm{ng} / \mathrm{h} \cdot \mathrm{mg} \text { protein) }\end{array}$ \\
\hline \multicolumn{3}{|l|}{ Wistar strain } \\
\hline $\begin{array}{ll}\text { Control } & (\mathrm{n}=11) \\
\text { Diabetic } & (\mathrm{n}=10)\end{array}$ & $\begin{array}{l}8.1 \pm 1.09 * \\
4.6 \pm 1.98\end{array}$ & $\begin{array}{r}946 \pm 139.0^{*} \\
1175 \pm 149.4\end{array}$ \\
\hline \multicolumn{3}{|l|}{ Wistar-kyoto strain } \\
\hline $\begin{array}{ll}\text { Normotensive } & (n=10) \\
\text { Hypertensive } & (n=10) \\
\text { Hypertensive + Diabetic } & (n=6)\end{array}$ & $\begin{array}{l}8.0 \pm 1.32 \\
5.9 \pm 1.22 \\
3.7 \pm 2.26\end{array}$ & $\begin{array}{l}\text { N.D. } \\
893 \pm 177.8 \\
901 \pm 113.8\end{array}$ \\
\hline
\end{tabular}

* Standard deviation; N. D., not determined.

However, the kallikrein content in hypertensive rats was $26 \%$ lower than that of normotensive rats (5.9 \pm 1.22 vs. $8.0 \pm 1.32$ )

On the other hand, the specific activity of renin in the kidney homogenates showed only slight changes in hypertension and diabetes. The renin activity of Wistar rats was $946 \pm 139.0$ (angiotensin $\mathrm{I}, \mathrm{ng} / \mathrm{h} \cdot \mathrm{mg}$ protein), which was approximately the same as the value in hypertensive rats $(893 \pm 177.8)$, although the activity in Wistar diabetic rats $(1175 \pm 149.4)$ was significantly higher $(p<0.005)$ than that of Wistar control rats.

\section{Discussion}

The importance of the renin-angiotensin system in the aetiology of some forms of hypertension is undisputed, and glandular kallikrein has been implicated in the regulation of blood flow to the exocrine glands and kidney, in water and electrolyte balance, and is also involved in the mediation of insulin action on blood glucose uptake by the skeletal muscle, and in the pathogenesis of experimental and human hypertension (12-15). Powers et al. and Celler et al. re- ported that glandular kallikrein in urine and the anterior pituitary decreased in hypertensive rats in comparison with the normal rats $(16,17)$. In contrast, we have previously reported that the glandular kallikrein content of the submaxillary gland tended to be higher than in normal rats (5), in spite of the fact that the submaxillary gland is a major source of glandular kallikrein in rat plasma (18). In order to clarify the discrepancy, the interrelation of the kallikrein-kinin, renin-angiotensin, and tonin-angiotensin systems in the submaxillary gland and the kidney were investigated in normal, hypertensive and diabetic rats.

Although the kallikrein of the submaxillary gland in hypertensive rats was higher than in the normotensive rats, the kallikrein in diabetic hypertensive rats decreased to the same level as in diabetic Wistar rats. However, the blood pressure showed only minor changes in spite of the remarkable reduction of the submaxillary gland kallikrein. On the other hand, the tonin activity of the submaxillary gland in hypertensive rats increased $28-29 \%$ in comparison with normotensive rats. Also, both the high tonin activity and high blood pressure in hypertensive rats were not 
changed by the induction of diabetes. Garcia et al. reported that the tonin concentration of the submaxillary gland in one-kidney hypertensive rats was significantly higher $(p<0.001)$ than in normotensive rats (19). From these results it may be suggested that tonin contributes to the maintainance of high blood pressure in spontaneously hypertensive rats. Nevertheless, the kallikrein and renin in the kidney cannot be neglected in the pathogenesis of hypertension, because the renin activity, which has a close interaction with kallikrein, has been implicated in human hypertension and in experimental hypertension (6, $20,21)$. In the present study, the kallikrein content in the kidney decreased by $43-54 \%$ in diabetes and hypertension in comparison with control and normotensive rats. On the other hand, the renin activity of the kidney in diabetes and hypertension showed slight changes in comparison with control rats. Kawashima et al. reported that a direct role of the renin-angiotensin system can be excluded in the maintainance of hypertension in spontaneous hypertensive rats (22). This can be concluded from the fact that no significant difference of kidney renin activity was seen between hypertensive and normotensive rats. Recently, in contrast to our results, Pratt et al. reported that diabetic rats were found to have lower plasma renin activity than non-diabetic controls (23). This discrepancy seems to be due to the more prolonged treatment

\section{References}

1. Kato, H., Enjyoji, K., Miyata, T., Hayashi, I., Ohishi, S. \& Iwanaga, S. (1985) Biochim. Biophys. Res. Commun. 127, 289-295.

2. Matoba, T., Murakami, K. \& Inagami, T. (1978) Biochim. Biophys. Acta 526, 560-571.

3. Ryan, J. W. \& Ryan, U. S. (1980) In: Enzymatic Release of Vasoactive Peptides (Gross, H. \& Vogel, G., eds.) pp. 259-273, Raven Press, New York.

4. Demassieux, S., Boucher, R., Grise, C. \& Genest, J. (1976) Can. J. Biochem. 54, 788-795.

5. Sakamoto, W., Yoshikawa, K., Nishikaze, O., Handa, H., Hirayama, A. \& Uehara, S. (1985) J. Clin. Chem. Clin. Biochem. 23, 521 - 523 .

6. Suzuki, S., Franco-Saenz, R., Tan, S. Y. \& Mulrow, P. J. (1980) J. Clin. Invest. 66, 757-762.

7. Bergmeyer, H. U. \& Bernt, E. (1974) In: Methods in Enzymatic Analysis (Bergmeyer, H.U., ed.) 3, pp. 1205-1215, Academic Press, New York.

8. Lowry, O. M., Rosebrough, N. J., Farr, A. L. \& Randall, R. J. (1951) J. Biol. Chem. 193, 265-275.

9. Inagami, T. \& Murakami, K. (1977) J. Biol. Chem. 252, $2978-2983$.

10. Haber, E., Koerner, T., Page, L. B., Kliman, B. \& Purnode, A. (1969) J. Clin. Endocrinol. Metab. 29, 1349-1355.

11. Izumi, H. (1984) Br. J. Pharmac. 82, 175-182.

12. Carretero, O. A. \& Scicli, A. G. (1978) Klin. Wochenschr. 56, Suppl. I, 113-125. with alloxan, namely 7 weeks, in comparison with 4 weeks in our experiment. In addition, it remains to be clarified whether the plasma renin activity reflects the renin activities in the submaxillary gland and kidney in the diabetic state.

Regarding the relationship between diabetes and glandular kallikrein, the kallikrein content of the submaxillary gland and kidney in diabetes decreased significantly $(\mathrm{p}<0.005)$ in comparison with normotensive and hypertensive rats. A decrease in the pancreas in diabetes was reported previously (5). The reduction of the kallikrein content in the kidney in diabetic rats is in good agreement with the data of Mayfield et al. (24). They also reported that the development of hypertension in streptozotocin-diabetic rats follows the decrease in renal kallikrein, and that the abnormality in kallikrein can be prevented by insulin treatment. This fact may reflect the fact that insulin treatment normalizes the levels in renal kallikrein, probably indicating that insulin is necessary for the activation of the enzyme.

In conclusion, from these results the tonin in the submaxillary gland and the renal kallikrein may play a role in the regulation of systemic blood pressure. However, it still remains to be clarified whether these enzymes release vasoactive substances in vivo, in hypertension and diabetes.

13. Carretero, O. A. \& Scicli, A. G. (1980) Am. J. Physiol. 238, F247-F255.

14. Levinski, N. G. (1979) Circ. Res. 44, $441-451$.

15. Dietze, G. (1982) Mol. Cell. Endocrinol. 25, 127-149.

16. Power, C. A., Baer, P. G. \& Nasjletti, A. (1984) Biochem. Biophys. Res. Commun. 119, 689-693.

17. Celler, R. G., Margolius, H. S., Pisano, J. J. \& Keiser, H. R. (1975) Circ. Res. 36/37 Suppl. I, I-103-I-106.

18. Lawton, W. J., Proud, D., Frech, M. E., Pierce, J. V., Keiser, H. R. \& Pisano, J. J. (1981) Biochem. Pharmacol. 30, $1731-1737$.

19. Garcia, R., Boucher, R., Gutkowska, J., Kondo, K., Demassieux, S. \& Genest, J. (1978) Clin. Sci. Mol. Med. 54, $457-461$.

20. Bühler, F. R. (1983) Clin. Exper. Hypertension, $A 5(7 / 8)$, 1395-1407.

21. Loudon, A., Bing, R. F., Swales, J.D. \& Thurston, H. (1982) Clin. Exper. Hypertension, A4(11/12), 2049-2061.

22. Kawashima, K., Shiono, K. \& Sokabe, H. (1980) Clin. Exper. Hypertension A2, 229-245.

23. Pratt, J. H., Parkinson, C. A., Weinsberger, M. H. \& Duckworth, W. C. (1985) Endocrinology 116, 1712-1716.

24. Mayfield, R. K., Margoliuis, H. S., Bailey; G. S., Miller, D. H., Sens, D. A., Squires, J. \& Namm, D. H. (1985) Diabetes 34, 22-28.

Associate Professor Dr. W. Sakamoto
Department of Biochemistry
School of Dentistry
Hokkaido University
Sapporo, Japan

